Pig Housing and the Environment

Occasional Publication No. 11-British Society of Animal Production 1987

edited by A. T. Smith and T. L. J. Lawrence

\title{
THE INFLUENCE OF PHOTOPERIOD AND LIGHT INTENSITY ON THE FARROWING SOW AND LITTER
}

\author{
W. J. MUTTON \\ MAFF/ADAS, Government Buildings, Grantham Road, Sleaford, Lincolnshire NG34 7NP
}

\section{INTRODUCTION}

$\mathbf{T}$ he Codes of Recommendation for the Welfare of Livestock, Pigs (MAFF, 1983) state that during daylight hours the level of natural or artificial lighting in buildings should allow all housed pigs to be seen clearly. However, no guidelines are given for the actual light intensity in the buildings. Previous work has suggested an improvement in performance from sows and piglets in the farrowing house, exposed to extended photoperiods but the effect of any variation in light intensity has not been determined. The purpose of this trial was to study the effect of light intensity, during extended photoperiods, on the farrowing sow and litter with the aim of providing practical recommendations for lighting levels.

\section{METHOD}

The trial was undertaken on a commercial unit, in two adjacent farrowing houses of identical lay-out. Groups

TABLE 1

Experimental design

$\begin{array}{cc}\begin{array}{c}\text { Farrowing house } 1 \\ \text { (treatment room) }\end{array} \\ \text { Group } & \begin{array}{c}\text { Light } \\ \text { intensity } \\ \text { (lux) }\end{array} \\ 1 & 700 \\ 2 & 500 \\ 3 & 400\end{array}$

Farrowing house 2 (control room)

$\begin{array}{cc}\text { Group } & \begin{array}{c}\text { Light } \\ \text { intensity } \\ \text { (lux) }\end{array} \\ 1 \mathrm{~A} & 50 \\ 2 \mathrm{~A} & 50 \\ 3 \mathrm{~A} & 50\end{array}$

RESULTS

TABLE 2

\begin{tabular}{|c|c|c|c|c|c|}
\hline $\begin{array}{l}\text { Light levels } \\
\text { (lux) }\end{array}$ & $\begin{array}{l}\text { Mean piglet } \\
\text { birth weight } \\
\quad(\mathrm{kg})\end{array}$ & $\begin{array}{l}\text { Mean piglet } \\
\text { weaning weight } \\
(\mathrm{kg})\end{array}$ & $\begin{array}{c}\text { Pre-weaning } \\
\text { mortality } \\
(\%)\end{array}$ & $\begin{array}{c}\text { Mean piglet } \\
\text { growth rate } \\
\text { (g/day) }\end{array}$ & $\begin{array}{l}\text { Mean weaning } \\
\text { to service interval } \\
\text { (days) }\end{array}$ \\
\hline $\begin{array}{l}700 \dagger \\
582 \cdot 7 \ddagger \\
327 \cdot 1 \S\end{array}$ & 1.44 & $5 \cdot 43$ & $5 \cdot 1$ & 204 & 4.9 \\
\hline $\begin{array}{l}500 \dagger \\
406 \cdot 6 \ddagger \\
184 \cdot 9 \S \\
400 \dagger\end{array}$ & 1.29 & $5 \cdot 80$ & $5 \cdot 5$ & 215 & $4 \cdot 4$ \\
\hline $\begin{array}{l}293 \cdot 6 \ddagger \\
135 \cdot 78\end{array}$ & 1.25 & $5 \cdot 39$ & $4 \cdot 3$ & 190 & $4 \cdot 5$ \\
\hline $\begin{array}{l}50 \dagger \\
40 \cdot 2 \ddagger \\
19 \cdot 5 \S\end{array}$ & $1 \cdot 33$ & $5 \cdot 65$ & $4 \cdot 4$ & 195 & $6 \cdot 1$ \\
\hline
\end{tabular}


of 24 multiparous sows were subjected to different light intensities provided by $65 \mathrm{~W}$ fluorescent tubes for a daily 18-h photoperiod, according to experimental design shown in Table 1.

Light intensities were calculated using a coefficient of reflectivity to take account of light reflection and absorption of the internal surfaces within the farrowing house. Light readings were taken at two points, $300 \mathrm{~mm}$ from the front of the farrowing crate, using a photometer: (1) at the level of a standing sow $(500 \mathrm{~mm}$ above floor); (2) at the level of a lying sow $(200 \mathrm{~mm}$ above floor). The photometer was tilted to intercept light from six directions (above and below each point, to the front and rear and from either side). These readings were averaged to give a representative light measurement for each crate.

\section{CONCLUSIONS}

(1) Statistical analysis of the results showed there to be no significant difference $(P<0.05)$ in piglet birth weights or piglet weaning weights, pre-weaning mortality or piglet growth rates between treatments.

(2) A shorter mean weaning-to-service interval was found with sows exposed to high light levels (calculated levels of 700,500 and $400 \mathrm{lux}$ ), but this was not significant.

(3) At higher light intensities (farrowing house 1) piglets were not easily attracted into forward creep areas, leading to an increased risk of overlaying. It is possible that the piglets could not differentiate between light from the creep lamp and the light level in the farrowing room and therefore were not encouraged to move into the creep area and away from the sow.

(4) Considerable variation between the calculated and actual light measurement was found. An even distribution of light intensity in each room was difficult to achieve, especially at lower light intensities where a reduced number of fluorescent tubes were used to provide the lighting in each room.

This trial has indicated the importance of actually stating how light readings are measured, when presenting values for light intensity, as the method of measurement will have a considerable effect on the final reading obtained. The variation and the departure of measured light intensities from calculated light levels highlights the difficulty in providing firm recommendations for lighting levels in buildings. There is no indication from this work that lighting intensity in the farrowing house significantly affects pig performance.

\section{REFERENCES}

CAdDY, S. D. and PeEt, B. J. 1985. The effect of diurnal lighting pattern in the farrowing house on the growth and viability of suckling piglets, and the return to oestrus in the sow. Animal Production 40: 547 (Abstr.).

Mabry, J. W., Coffey, M. T. and Seerley, R. W. 1983. A comparison of an eight versus sixteen hour photoperiod during lactation on suckling frequency of the baby pig and maternal performance of the sow. Journal of Animal Science 57: 292-295.

Mabry, J. W., Cunningham, F. L., Kraeling, R. R. and RAmpaceK, G. B. 1982. The effect of artificially extended photoperiod during lactation on maternal performance of the sow. Journal of Animal Science 54: 918-921.

Ministry of Agriculture, Fisheries and Food. 1983. Codes of Recommendations for the Welfare of Livestock, Pigs. Her Majesty's Stationery Office, London.

Stevenson, J. S., Pollman, D. S., Davis, D. L. and Murphy, J. P. 1983. Influence of supplemental light on sow performance during and after lactation. Journal of Animal Science 56: 1282-1286. 